\title{
Self-Regulation Strategies of Students Enrolled in a Distance and Online University Education Program ICWL 2019
}

\author{
Louise Sauvé \\ Professor, Education Department, TELUQ University \\ Director of Centre of Research in LifeLong Learning (SAVIE)
}




\section{Associated Presenters}

Nicole Racette, Professor, University TÉLUQ

Cathia Papi, Professor, University TÉLUQ

Serge Gérin-Lajoie, professor, University TÉLUQ

villaume Desjardins, research and coordination assistant

Sophie Marineau, research assistant

\section{Team}

Other members of the research team

Séverine Parent, professor, UQAR

Didier Paquelin, professor, UL

Martin Houde, professor, University TÉLUQ

Sandrine Marineau, research assistant 


\section{Overview}

1. Context of research

2. Methodology

3. Results and discussion 


\section{Context}

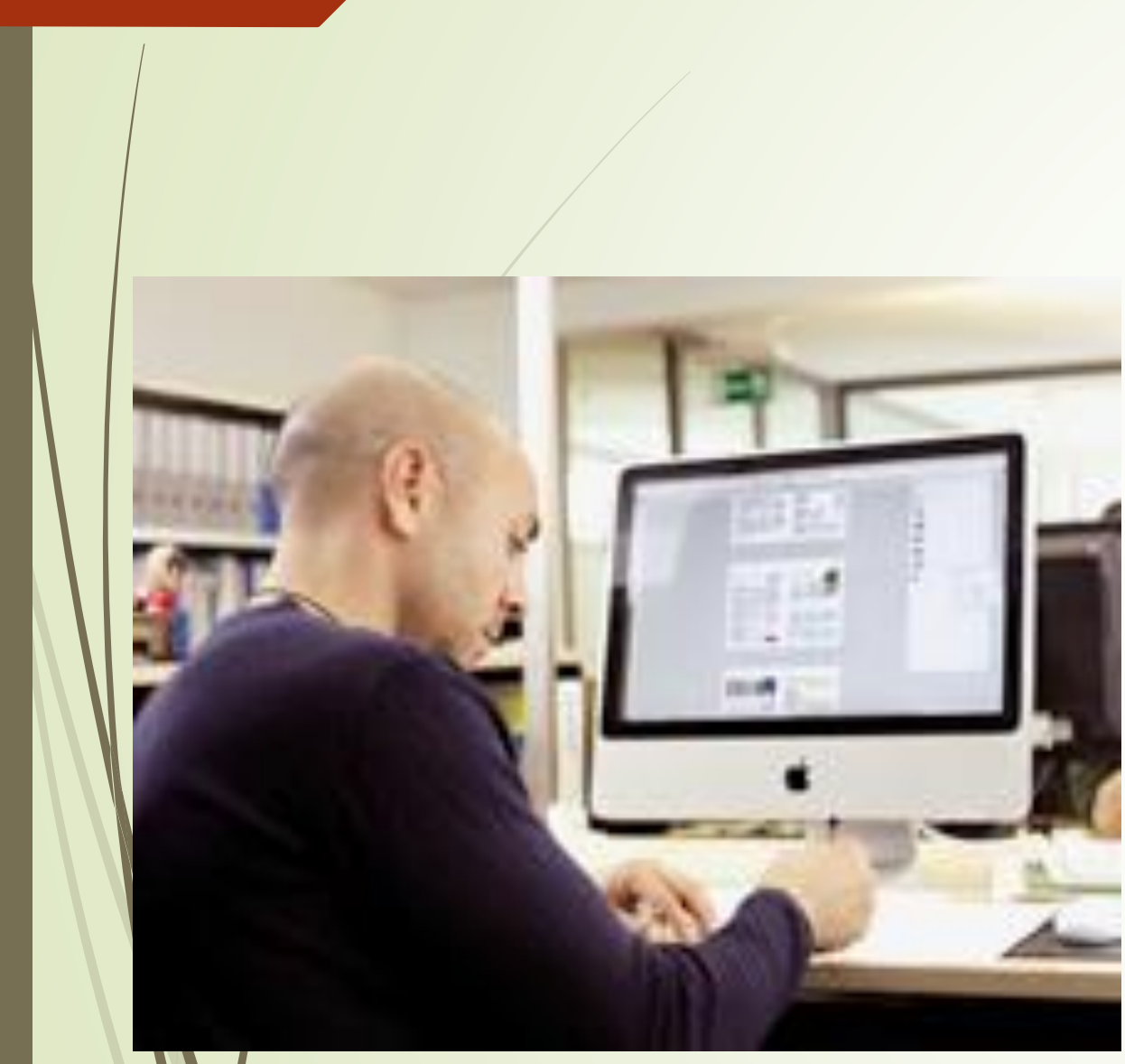

- The lack of learning strategies, especially self-regulation strategies for students in the context of Distance and Online Learning (DOL)

- $\mathrm{DOL}=$ an education (synchronous and asynchronous) where the teaching and learning activities are overall carried out using Web technologies 


\section{Sociodemographic Variables}

- The gender variable does not seem to have a significant impact on the drop-out rate.



- Students grow older, participation in postsecondary studies and drop-out rates tend to increase

- The university drop-out rate is lower among students with a parent who has a post-secondary diploma (12\%) than those whose parents have no post-secondary education (20\%)

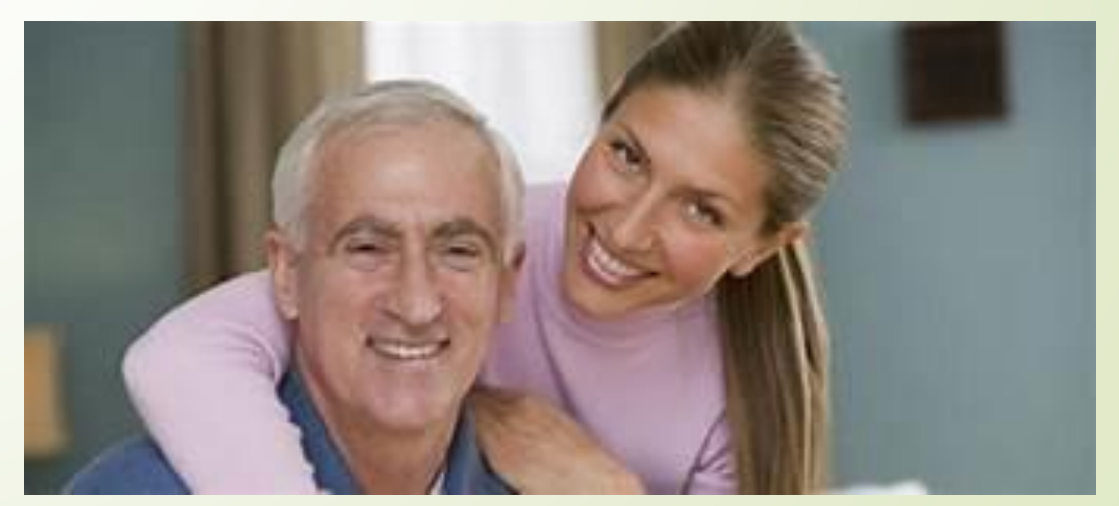




\section{Academic Variables}

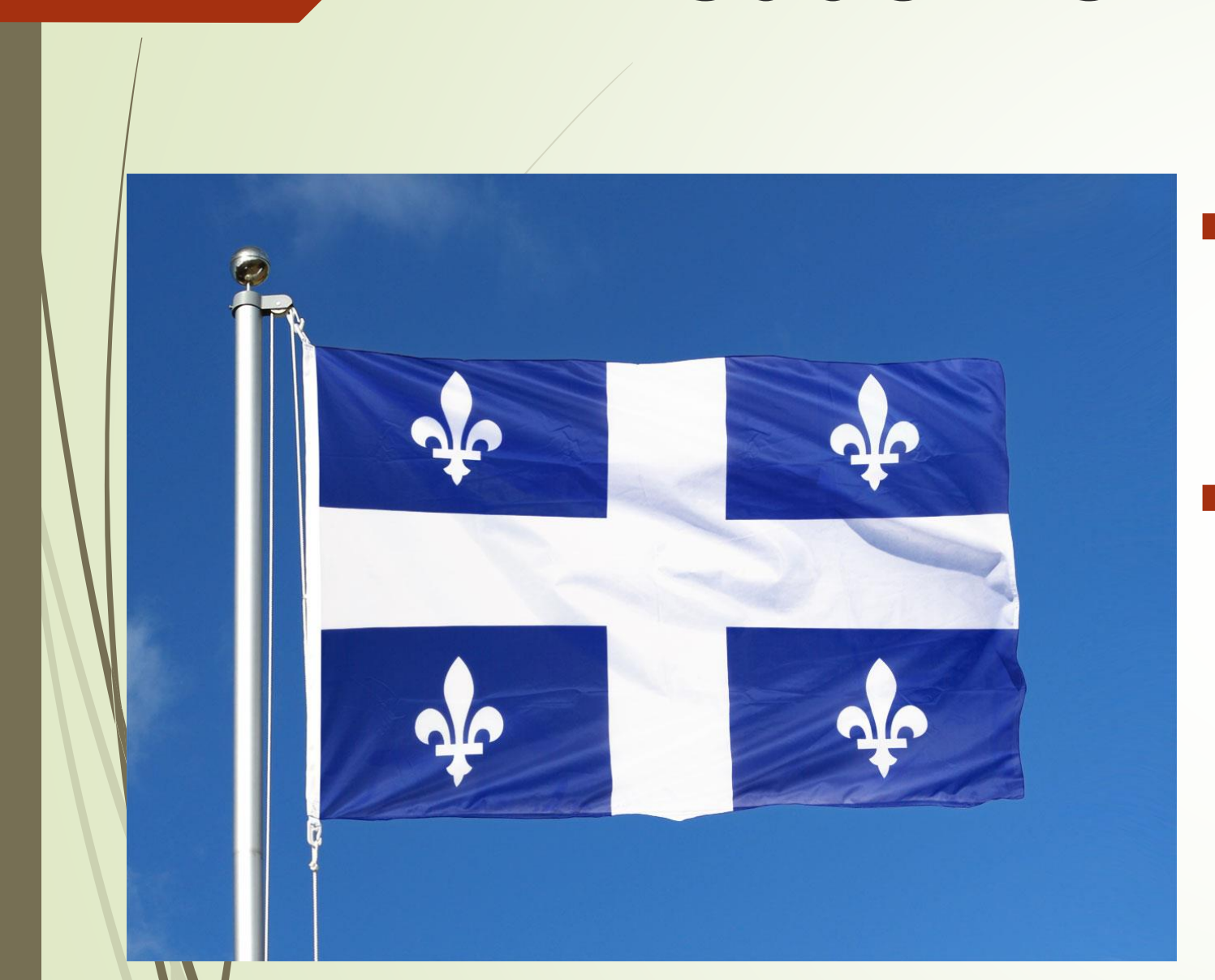

- In Quebec, $33 \%$ of students abandon their university studies when they are in a bachelor's program

- Nearly half of these drop-outs occur during the first year of enrolment in a bachelor's program 


\section{Self-regulation strategies}

Self-regulating mental operations based on metacognitive knowledge, consisting mainly of planning, mobilizing and managing the external and internal resources required for the intended learning

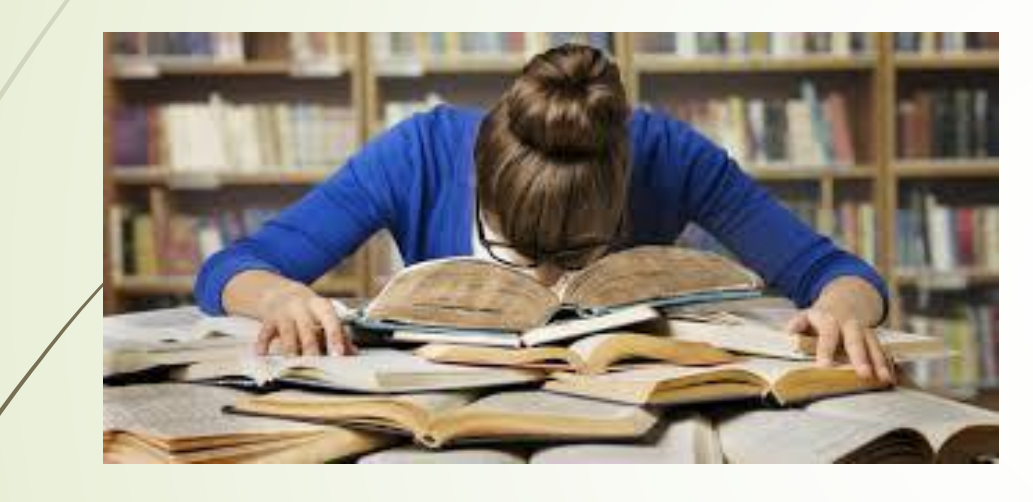

- For external resources, we find management strategies for the workspace and tasks as well as time.

- For internal resources : emotional strategies that affect the maintenance of motivation, concentration, confidence in ability to succeed in school, management of stress and asking for help.

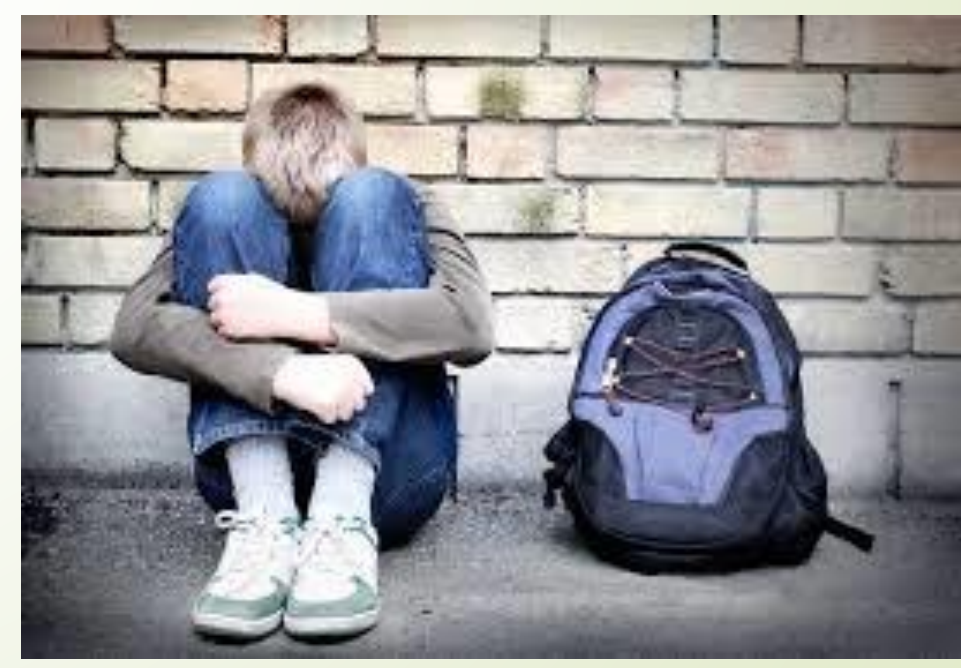




\section{Problem}

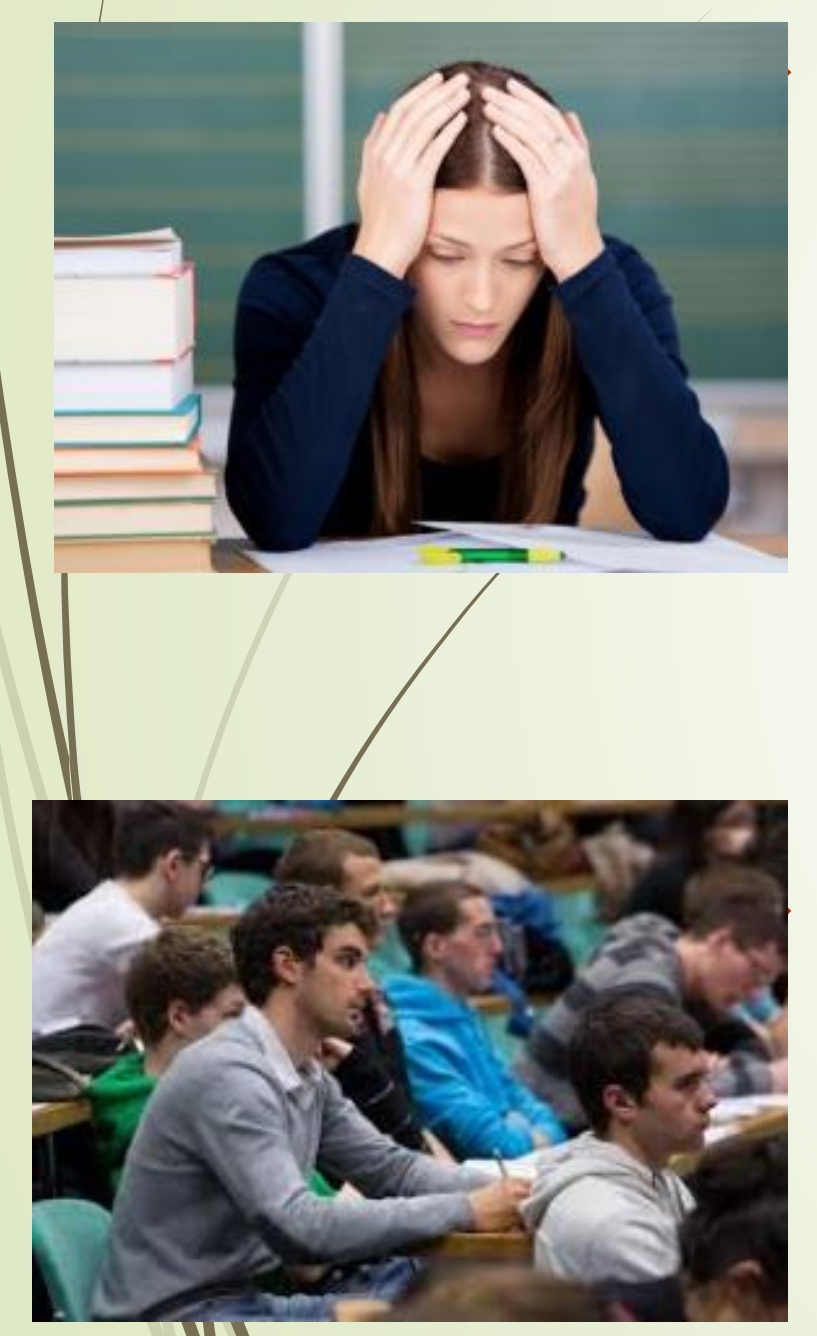

Students do not seem to have clear ideas about the learning strategies they use.

Since learning strategies can be innate as well as learned, learning and gaining knowledge about these strategies can lead students to better understand their behaviour toward studying. 


\section{Overview}

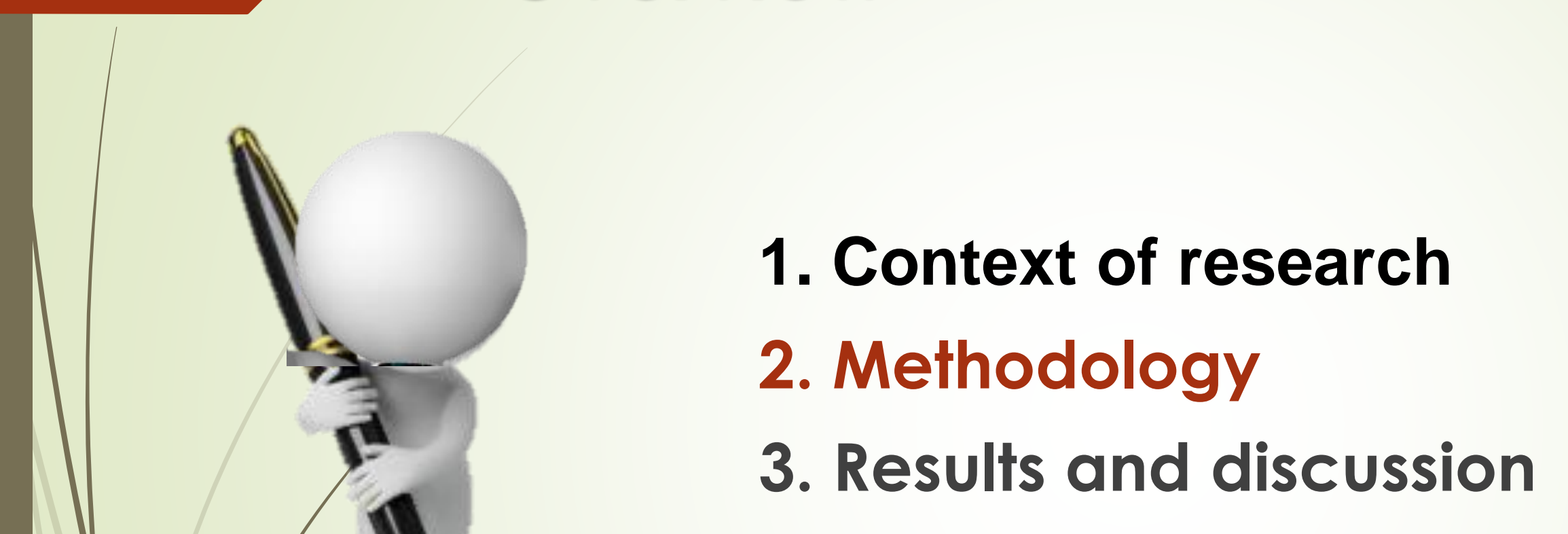




\section{Sample}

Three elements were taken into account for the choice of courses.

- The selected courses came from at least three different departments (language department, social sciences and administrative sciences).

- The number of students per course, between $\mathbf{3 0 0}$ at 900 registrations per year.

- The variability of the courses in terms of the rates of failure, drop-outs and success : 17 selected courses have failure variations ranging from $5.95 \%$ to $23.64 \%$ and drop-outs between $8.86 \%$ and $17.34 \%$. 


\section{Methodology - Sample $(n=1060)$}

\begin{tabular}{|c|l|c|}
\hline Characteristics & \multicolumn{1}{|c|}{ Demographic Variables } & Respondents \\
\hline Gender & Female & $75.8 \%$ \\
& Male & $24.2 \%$ \\
\hline \multirow{2}{*}{ Age } & 25-34 years old & $44.7 \%$ \\
& 35-44 years old & $14.9 \%$ \\
& Over 45 years old & $11.1 \%$ \\
\hline \multirow{2}{*}{ Family Life } & Live with a spouse and children & $67.1 \%$ \\
& Live alone with or without children & $32.9 \%$ \\
\hline \multirow{2}{*}{ Marital Status } & Live with partner (married or common & $63.6 \%$ \\
& law) & $32.9 \%$ \\
& Single & $3.4 \%$ \\
\hline
\end{tabular}




\section{Methodology - Sample $(n=1060)$}

\begin{tabular}{|c|l|c|}
\hline Characteristics & \multicolumn{1}{|c|}{ Academic Variables } & Respondents \\
\hline \multirow{3}{*}{ Semester } & 1th to 3th semester & $67.6 \%$ \\
\cline { 2 - 3 } & 4th to the 6th semester & $16.9 \%$ \\
\cline { 2 - 3 } & 7th to 9th semester & $10.8 \%$ \\
\cline { 2 - 3 } Program & $4.7 \%$ \\
\hline \multirow{3}{*}{} & Certificate program (30 credits) & $54.6 \%$ \\
\cline { 2 - 3 } & Bachelor's degree (90 credits) & $32.8 \%$ \\
\cline { 2 - 3 } & Short program (between 9 and 15 credits) & $6.6 \%$ \\
\hline
\end{tabular}




\section{Data collection Instrument}

Online questionnaire complete during three sessions (Summer and Fall 2018, Winter 2019).

- In the first part, 21 statements to identify socio-demographic and academic variables

- In the second part, 37 statements deal with self-regulation strategies grouped into 7 categories:

- task management (6 statements)

- time management (4 statements)

- concentration (3 statements)

- confidence in ability to succeed (7 statements)

- motivation (8 statements)

- stress (5 statements)

- asking for help (4 statements) 


\section{Statistical analysis}

1. Reliability analysis of the statements according to their respective category

2. Analysis of the Cronbach alpha (a) coefficient was performed (between 0.584 and 0.72 )

3. Variances between the categories mentioned were analyzed with respect to the various socio-demographic factors observed among students: age group, civil status, number of semesters of study in DOL, type of program, parents' schooling 4. Post-hoc test (Tukey) 


\section{Overview}

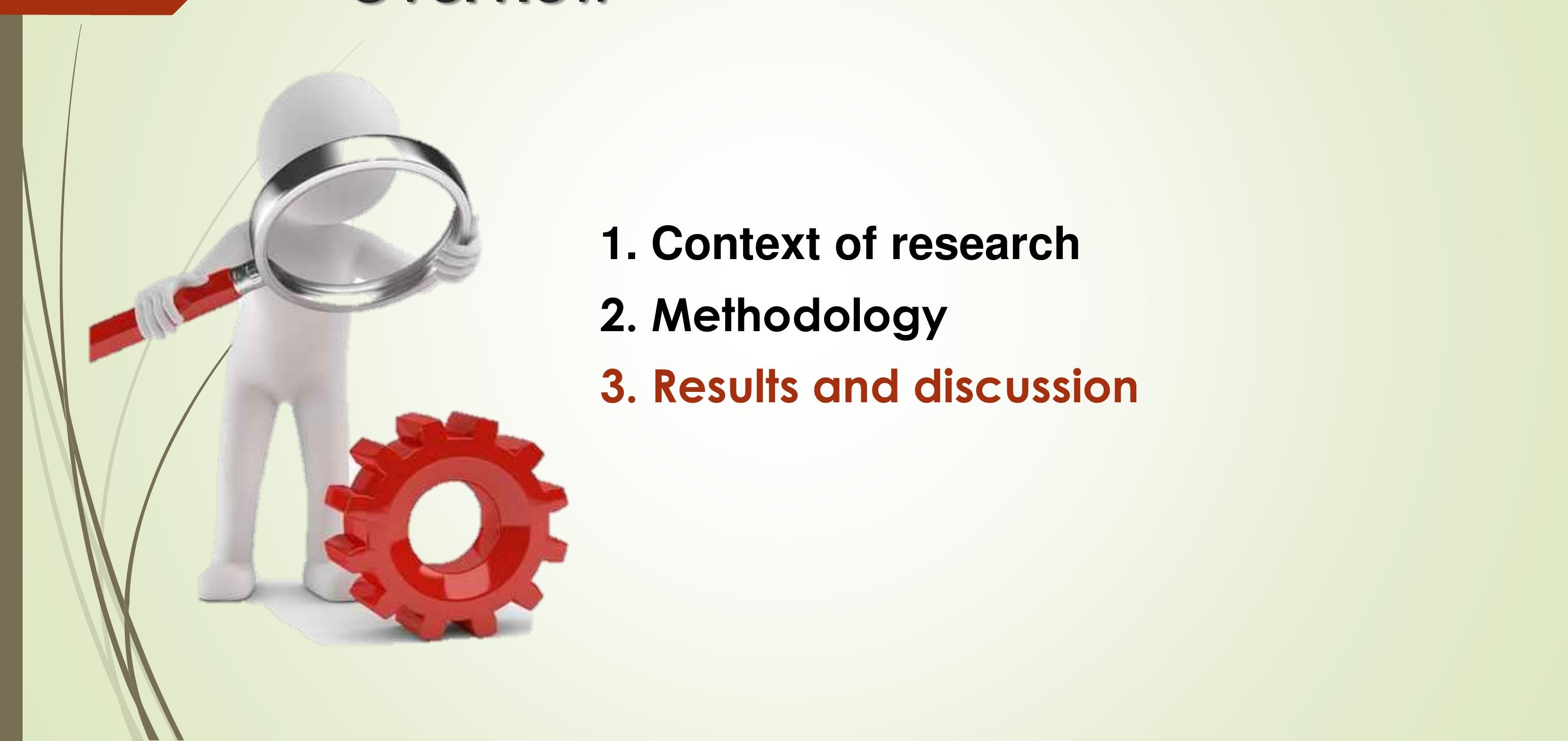


Self-Regulation Strategies Used by Respondents

$$
(n=1,060)-82.66 \%
$$

\begin{tabular}{|c|l|l|l|}
\hline Categories & \multicolumn{1}{|c|}{ Self-Regulation Strategies } & Used \% & Not Used \% \\
\hline & $\begin{array}{l}\text { My choice of courses } \\
\text { corresponds to my interests or } \\
\text { professional requirements }\end{array}$ & $\mathbf{9 6 . 0}$ & 4 \\
\hline $\begin{array}{l}\text { Motivation } \\
\text { I really feel like I'm wasting my time in } \\
\text { university courses }\end{array}$ & 6.8 & 93.2 \\
\hline $\begin{array}{l}\text { Having a university degree is } \\
\text { very important to me }\end{array}$ & 95.1 & 4.9 \\
\hline $\begin{array}{l}\text { I am usually satisfied with what I } \\
\text { achieve in my courses }\end{array}$ & 92.7 & 7.3 \\
\hline $\begin{array}{l}\text { I see the link between my courses and } \\
\text { the professional practice being } \\
\text { exercised or sought }\end{array}$ & 92.0 & 8.0 \\
$\begin{array}{l}\text { I am pleased with taking my course } \\
\text { online }\end{array}$ & 88.2 & 11.8 \\
\hline
\end{tabular}


Self-Regulation Strategies Used by Respondents $(n=1,060)-82.66 \%$

\begin{tabular}{|c|c|c|c|}
\hline Categories & Self-Regulation Strategies & Used \% & Not Used \% \\
\hline \multirow[t]{2}{*}{$\begin{array}{l}\text { Task } \\
\text { Management } \\
\text { (2/6 statements) }\end{array}$} & $\begin{array}{l}\text { I create an atmosphere that can } \\
\text { facilitate my educational tasks (music, } \\
\text { going to the library, setting up a workplace, } \\
\text { etc.). }\end{array}$ & 90.0 & 10.0 \\
\hline & $\begin{array}{l}\text { When I'm dealing with a difficult task, I divide } \\
\text { it into several small tasks }\end{array}$ & 85.7 & 14.3 \\
\hline \multirow{5}{*}{$\begin{array}{l}\text { Confidence in } \\
\text { Ability to } \\
\text { Succeed } \\
\text { (5/7 statements) }\end{array}$} & $\begin{array}{l}\text { I feel able to pass my exams and do } \\
\text { well in my assignments }\end{array}$ & 95.1 & 4.9 \\
\hline & $\begin{array}{l}\text { I take initiatives in my studies to make sure I } \\
\text { succeed }\end{array}$ & 94.3 & 5.7 \\
\hline & I feel able to make steady progress & 91.7 & 8.3 \\
\hline & $\begin{array}{l}\text { I have confidence in my ability to use } \\
\text { effective learning strategies }\end{array}$ & 91.1 & 8.9 \\
\hline & $\begin{array}{l}\text { I call into question my work methods when my } \\
\text { results are not up to my expectations }\end{array}$ & 88.1 & 11.9 \\
\hline
\end{tabular}


Self-Regulation Strategies Not Used by Respondents $(n=1,060)-26.9 \%$

Categories
$\begin{gathered}\text { Task Management } \\ \text { (1/6 statements) }\end{gathered}$
Time Management
(3/4 statements)

I plan work periods based on when I'm most productive.

69.7

30.3

I estimate how much time my work will take in order to avoid being late.

68.6

31.4

I can fix a study schedule and adhere to it.

70.7

29.3

Concentration I can maintain my attention and concentration adequately.

(2/3 statements) I can concentrate easily in this course.

68.7

29.3

Confidence in

Ability to Succeed (1/7 statements)

I can get down to work without any difficulty to speak of. 68.2

31.8

I can normally manage stress and pressure when

Stress

(2/5 statements) studying.

68.2

31.8

Normally, I can control my fear or worry when I do learning activities.

52.6

47.4

When I need help, I turn to other students.

61.0

39.0

Asking for Help (2/4 statements)

I communicate with other students when I need support for learning 


\section{Analysis of the variances between the categories}

\begin{tabular}{|l|l|l|l|}
\hline Category & Variables & F & p \\
\hline Concentration & Age Grouping & 1.864 & 0.041 \\
& Civil Status & 1.816 & 0.048 \\
\hline Motivation & Age Grouping & 1.681 & 0.026 \\
\hline Asking for Help & Age Grouping & 2.394 & 0.002 \\
& Type of Program & 2.122 & 0.006 \\
& Civil Status & 1.976 & 0.012 \\
& Family Situation & 1.8 & 0.027 \\
\hline $\mathbf{N}=\mathbf{9 6 5 \quad 1}$ The analyses are univariate. & & \\
\hline
\end{tabular}




\section{General portrait of the student in relation to their use of self-regulation strategies.}

- For task management, group 2 on average uses these strategies more than group 3

- For the category concentration, group 3 on average uses these strategies less than group 1

- For the category asking for help, group 1 on average uses these strategies more than groups 2 and 3

\begin{tabular}{|c|c|c|c|c|}
\hline Cluster & $N(\%)$ & Family Situation & Civil Status & Age Grouping \\
\hline 1 & $\begin{array}{c}315 \\
(32.6 \%)\end{array}$ & Lives alone & Single & $\begin{array}{c}\text { Less than } 25 \\
\text { years old }\end{array}$ \\
\hline 2 & $\begin{array}{c}263 \\
(27.3 \%)\end{array}$ & Lives with spouse & Common-law partner & $25-34$ years old \\
\hline 3 & $\begin{array}{c}387 \\
(40.1 \%)\end{array}$ & $\begin{array}{c}\text { Lives with spouse } \\
\text { and child(ren) }\end{array}$ & $\begin{array}{c}\text { Common-law } \\
\text { partner/ married }\end{array}$ & $35-44$ years old \\
\hline
\end{tabular}




\section{Discussion}

- The academic variable, the number of sessions or academic year, does not seem to have a significant influence on the use or non-use of self-regulation strategies by DOL students.

- The combination of variables (age, civil status and family situation) revealed three profiles of students who use fewer self-regulation strategies (time management, asking for help and concentration) in $\mathrm{DOL}$ 


\section{Discussion}

- Using a cluster model to identify three typical student profiles makes for a more encompassing and realistic analysis than a factorial analysis of variance.

- For example, with strategies for task management which become statistically significant when analysis of age, civil status and family situation are combined.

- It is therefore possible to argue that certain selfregulation strategies should not be studied according to a single criterion, but rather by combining various sociodemographic aspects of a university student's typical situation. 


\section{Limitations}

- Only $27 \%$ of people from our population responded to the survey.

- Our sample is made up of more women than men.

A population analysis is underway to verify if the characteristics of our respondents reflect those of the population

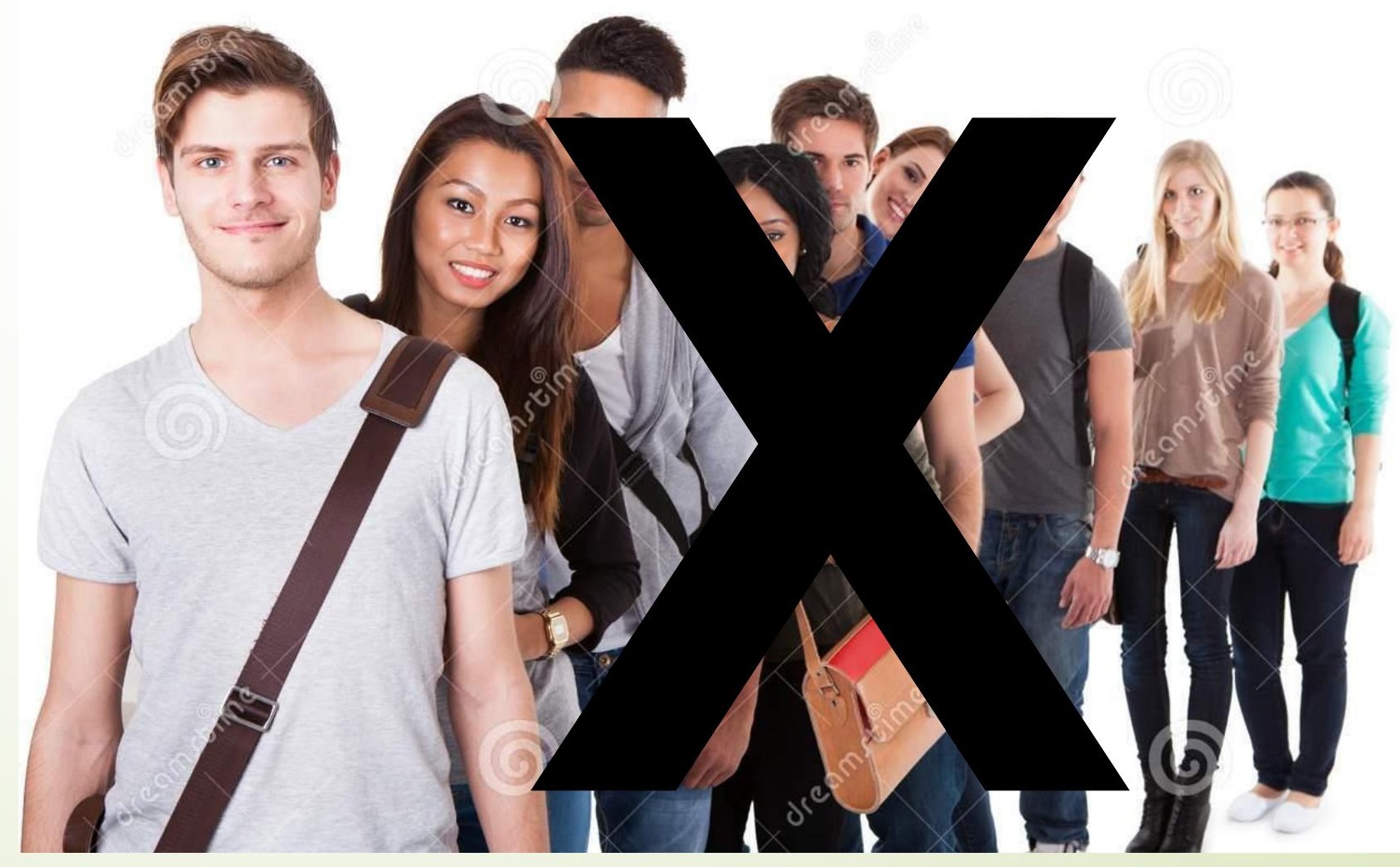




\section{Conclusion}

- Various findings have been identified which will be used in the second phase of our study, namely to determine whether these strategies influence dropping out of a distance and online course.

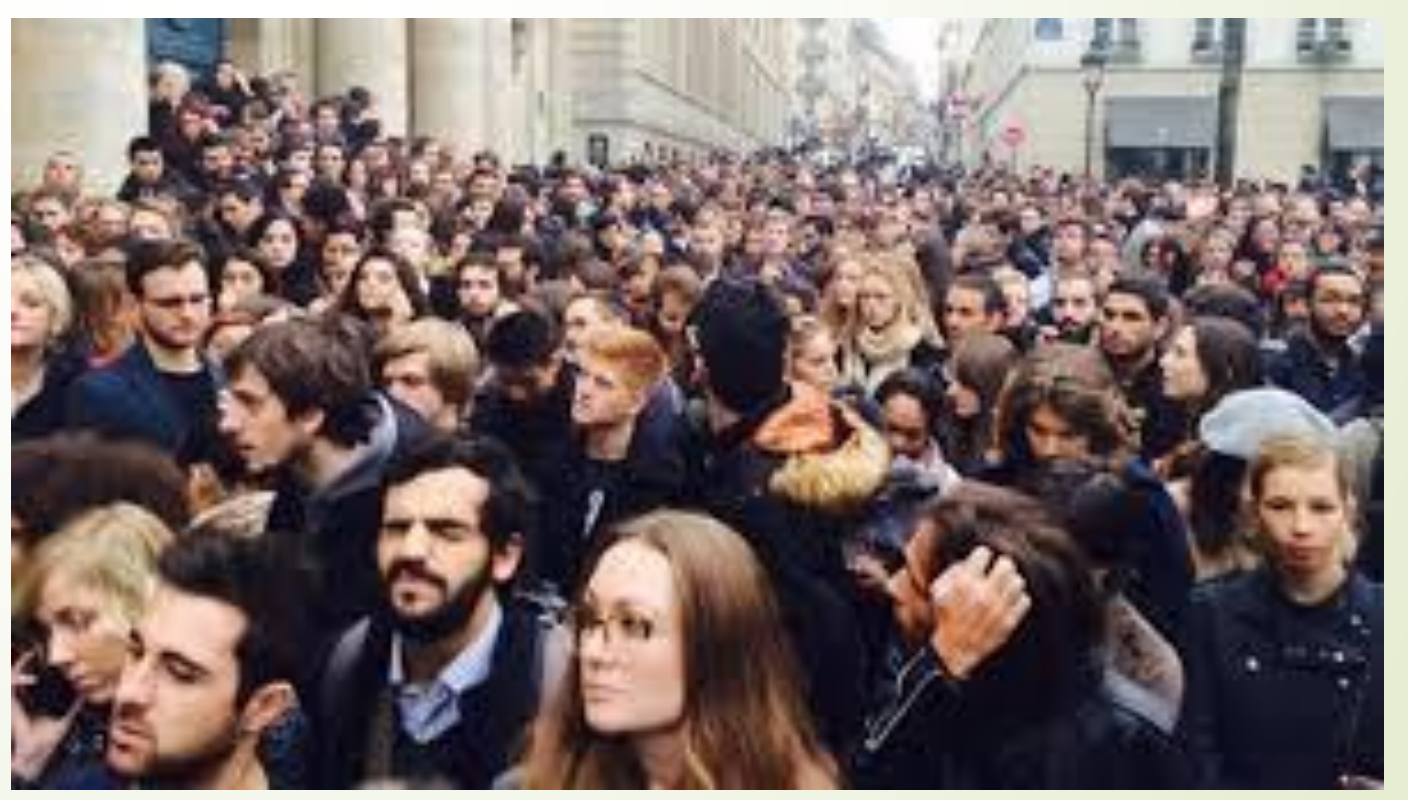


